\title{
Binding site locations and interaction of the isolated middle loop of snake neurotoxin I with muscle type nicotinic acetylcholine receptor: molecular dynamics and docking simulation study
} Adak Nasiripourdori*, Bijan Ranjbar and Hossein Naderi-manesh

\author{
Address: Department of Biophysics, Faculty of Sciences, Tarbiat Modares University, P.O.Box 14115-175, Tehran, Iran \\ Email: Adak Nasiripourdori* - nasiripour@modares.ac.ir \\ * Corresponding author
}

from BioSysBio 2007: Systems Biology, Bioinformatics and Synthetic Biology Manchester, UK. II-13 January 2007

Published: 8 May 2007

BMC Systems Biology 2007, I (SuppI I):P73 doi:I0.I I86/I752-0509-I-SI-P73

This abstract is available from: http://www.biomedcentral.com/I752-0509/I?issue=SI

(c) 2007 Nasiripourdori et al; licensee BioMed Central Ltd.

Acetylcholine receptors are members of the superfamily of ion channel-coupled receptors which are gated by specific neurotransmitters and mediate the passage of potassium and sodium ions across synaptic membranes, two main classes of which are neuromuscular and neuronal AchRs [1-3]. The three-fingered alpha neurotoxins are specific antagonists of nicotinic acetylcholine receptors (nAChRs)[3,4]. Because of the high degree of specificity and selectivity of snake neurotoxins, they are considered as invaluable candidates that serve as templates for drug design in treatment of diseases involving nAChRs. In order to better understand the details of their interaction with nAChRs, we performed a docking simulation study with the program FTdock. The loop II (middle finger) of the long chain neurotoxins which is believed to contribute mainly in binding and/or interaction of long chain neurotoxins with muscle type nAChR, was isolated from the main frame of alpha neurotoxin I from Naja oxiana $(1 \mathrm{~W} 6 \mathrm{~B})[4,5]$. The isolated loop II consisted of 31 amino acids (from cys 15 to ala 45) with a dominate beta structure, and two disulphide bonds. Prior to docking simulation, both the isolated structure and the long chain neurotoxin were submitted to a molecular dynamic (MD) simulation of 20 and 10 nano seconds, respectively. Selected snapshot structures along each MD trajectory were then subjected to the FT docking. The best-scored complexes were further refined with multidock program associated with 3D-Dock suite. Finally, the binding modes and amino acid residues involved in both receptor and the ligands were found and compared. The results show two main binding modes for the isolated 31-mer fragment: the principal one ( $\sim 80 \%$ ) locating in the lumen of the extracellular domain of the channel, the site that is usually occupied by non-competitive antagonists of nAChRs and physically blocks the entrane pore $[6,7]$. Another binding site for the 31-mer peptide was located on only one of the known competitive antagonists' binding sites $(\sim 20 \%)$. Comparative study of docking of long chain neurotoxin with the same receptor shows two main binding sites (alpha/gamma and alpha/delta), with a preferential tendency for one of the antagonists binding sites over the other. The results reveal the somehow underestimated role of loops III and I of long chain neurotoxins in the binding and/or recognition nAChRs, and offers a better understanding of the factors involved in antagonist binding mechanisms.

\section{References}

I. Unwin N: Refined Structure of the Nicotinic Acetylcholine Receptor at 4 Å Resolution. J Mol Biol 2005, 346:967-989.

2. Henchman RH, Wang H, Sine SM, Taylor P, McCammon JA: LigandInduced Cnformational Change in the a7 Nicotinic Receptor ligand Binding Domain. Biophysical Journal 2005, 88:2564-2576.

3. Henchman RH, Wang H, Sine SM, Taylor P, McCammon JA: Asymmetric Structural Motions of the homomeric a7 Nicotinic Receptor Lgand Binding Domain Revealed by Molecular Dnamics Simulation. Biophysical Journal 2003, 85:3007-30I8. 
4. Unwin N, Myazawa A, Li J, Fujiyoshi Y: Activtion of the Nicotinic Acetylcholine Receptor involves a Switch in Conformation of the subunits. J Mol Biol 2002, 319: I I65-1 I76.

5. Mordvintsev DY, Poyak YL, Levtsova OV, Tourleigh YV, Kasheverov IE, Shaitan KV, Utin YN, Tsetlin VI: A Model for short $\alpha$-neurotoxin bound to nicotinic acetylcholine receptor from Torpedo californica: Comparison with long-chain $\alpha$-neurotoxins an $\alpha$-conotoxins. Comput Biol Chem 2005, 29:398-4II.

6. Nirthanan S, Gwee MCE: Three Finger a-Neurotoxins and the Nicotinic Acetylcholine Receptor, Forty years on. Journal of Pharmacological Sciences 2004, 94: I- 17.

7. Arias HR: Localization of agonist and competitive antagonist binding sites on nicotinic acetylcholine receptor. Neurochemistry International 2000, 36:595-645.

Publish with Bio Med Central and every scientist can read your work free of charge

"BioMed Central will be the most significant development for disseminating the results of biomedical research in our lifetime. "

Sir Paul Nurse, Cancer Research UK

Your research papers will be:

- available free of charge to the entire biomedical community

- peer reviewed and published immediately upon acceptance

- cited in PubMed and archived on PubMed Central

- yours - you keep the copyright

Submit your manuscript here:

http://www.biomedcentral.com/info/publishing_adv.asp 